\title{
Responses of Tomato Varieties to Rainy Season Production under Low Cost Plastic Shelter
}

\author{
Dessie Getahun \\ Ethiopian Institute of Agricultural Research (EIAR) Fogera Research Center
}

*Corresponding Author: Dessie Getahun, Ethiopian Institute of Agricultural Research (EIAR) Fogera Research Center

\begin{abstract}
Acclimatization and performance of eleven varieties of tomato were evaluated for rainy season production under low cost plastic shelter. Randomized complete block design with three replications was employed. Varieties Melkashola (375.68 qt/ha) and Melksalsa (386.68 qt/ha) performed best and produced significantly $(P<0.05)$ high marketable fresh tomato yield per hectare. Moreover, yield per plant was significantly high from these two varieties $1.7 \mathrm{~kg}$ per plant from variety Melksalsa and $1.6 \mathrm{~kg}$ per plant for variety Melkshola. Percent non- marketable fruit number was also significantly low from Variety Melkshola (20.92\%), while the highest non-marketable fruit number was recorded from varieties Fetan (36.45\%) and Eshet $(35.71 \%)$. On the other hand, varieties Eshet $(5.98 \mathrm{~cm})$ and ARP $(5.65 \mathrm{~cm})$ had significantly high fruit width.

Melkasalsa and Melkashola suited most to plastic rain shelter production bringing about the highest performance in yield. Rainy season tomato production under plastic shelter would therefore contribute towards improving fresh tomato supply during the rainy season benefiting both actors involved in this sector including growers, consumers, traders and brokers. This practice would assist in avoiding fungicide application thereby protecting the environment from hazardous effect of chemicals. Plastic shelter gives protection to tomatoes from natural hazardous such as hail and strong wind. This practice of tomato production with high yield and good quality will enable growers to fetch high price from rainy season tomatoes and enhance year round fresh tomato supply.
\end{abstract}

Keywords: Disease, fungicide, hail, marketable yield, quality, year round supply

\section{INTRODUCTION}

Tomato (Lycopersicon esculentum Mill.) is the second most important vegetable in economic importance and consumption in the world, second only to potatoes (Ibitoye et.al, 2009). It is the most popular vegetable crop with versatile culinary uses. From processing to fresh market, and from sauce to juice and salad, the variety and usefulness of the fruit is virtually boundless. It can be eaten raw in salads or cooked, fried or sundried (ARC, 2013). Tomato fruits provide micronutrients, fiber, vitamins and minerals essential for a balanced and healthy diet. Tomato is a rich source of vitamins A and C, potassium and fiber. It is also rich in lycopene (Dimascio et al., 1989; Trinklein, 2010), the pigment that makes tomatoes red and has been linked to the prevention of or fight against many forms of cancer. Furthermore, Tabasi et.al (2013) indicated that lycopene is the leading factor to health promoting ability of tomatoes.

Tomatoes are major sources of cash income for smallholder as well as commercial farmers in Ethiopia. They are, however conventionally grown in an open field condition during the dry periods using irrigation. On the other hand, rain fed tomato production in an open field was considered difficult mainly because of disease attack leading to complete destruction of tomato plants. Seasonality in tomato production and concomitantly abundance and scarcity in supply is reflected, bringing about discrepancy in supply and demand for fresh tomatoes (Getahun, 2017). Fresh tomato supply is high in the dry season causing a market glut and falling prices.

Despite the importance of tomatoes in the daily diet of the people and ever increasing demand for this crop, fresh tomatoes supply during the rainy period is limited and the price climbs up. Periods of critical shortage for fresh tomatoes in many areas in Ethiopia especially in Amhara region is from 
June to October when prices are exorbitant (Getahun, 2015). Rainy season tomato fruits are quite remunerative business as the supply is low and price is high. Kirimi et.al (2011) also reported that fluctuations in the supply of tomatoes in the Kenyan market leading to market glut during in season and shortage during off season. Furthermore, Srinivasan (2011) showed that protective structures enable growers to produce tomatoes successfully during the off season, which enhances the availability of fresh produce at times when they are usually in short supply. Because prices are high during the off season, growers also enjoy higher return per unit area.

Tomato production during rainy season in open field condition is very difficult mainly due to serious disease attack. Integrated approaches for rain fed tomato production in open field condition through the use of disease tolerant varieties and applications of fungicides were evaluated by Fogera Research Center. It was however compulsory to use repeated and massive applications of fungicides, whose direct and residual effect is, however hazardous to human health and the environment in general. It is therefore critical to devise appropriate production system affordable by growers that could avoid or minimize the use of fungicides and ensure constant supply of fresh tomatoes throughout the year with an uninterrupted production both in the dry and rainy seasons. Rainy season tomato production under low cost plastic shelter by avoiding direct contact of rain with tomato foliage avoids favorable condition for disease development. This practice is therefore helpful to produce tomatoes without the use of fungicides contributing towards ensuring continuous production and constant supply of fresh tomatoes throughout the year. Furthermore by improving the microclimatic condition such as raising the temperature under the shelter, favorable environment for the production of high tomato yield with superior quality will be created. Plastic shelter also protects tomato plants from devastating natural hazards such as hail and strong wind. Varieties recommended for tomato production under plastic rain shelter were not however available to date. This study was therefore initiated to evaluate acclimatization and responses of varieties to this production system ultimately aiming to identify varieties suitable for rainy season tomato production under low cost plastic shelter.

\section{MATERIAL AND MethodS}

Field experiments under plastic shelter were carried out at Fogera Research Center during the rainy seasons from 2016 to 2018. The Center is located at the south periphery of Woreta town of Fogera district of South Gondar Administrative zone in Amhara Region, Ethiopia. Woreta lies at $11^{\circ} 58^{\prime} \mathrm{N}$ latitude and $37^{\circ} 41^{\prime} \mathrm{E}$ longitude. It has an altitude of $1819 \mathrm{~m}$ above sea level and receives average annual rainfall of $1230 \mathrm{~mm}$. Mean minimum and maximum temperature of the area is 12 and $28^{\circ} \mathrm{C}$, respectively. The soil is red clay (vertisol) rich in underground water.

\subsection{Varieties and Design}

Seeds of eleven improved varieties of tomato were obtained from Melkassa agricultural research center of the Ethiopian Institute of Agricultural Research. Varieties were Metadel, Miya, Cochoro, Gelilema, Fetan, Bishola, Eshet, ARP, Chali, Melkashola and Melkasalsa. These eleven varieties were laid in randomized complete block design with three replications. Total plot size used for each variety was $11.2 \mathrm{~m}^{2}(2.8 \mathrm{~m} \mathrm{x} 4 \mathrm{~m})$ accommodating 28 plants in four rows while effective plot size was $5.6 \mathrm{~m}^{2}$ $(2.8 \mathrm{~m} \times 2 \mathrm{~m})$ which contained 14 plants in two rows for yield and other data recording. Spacing between plants and rows were, in that order, $0.4 \mathrm{~m}$ and $1 \mathrm{~m}$. Gangways in between plots and replications were $1 \mathrm{~m}$ and $1.5 \mathrm{~m}$, respectively.

\subsection{Seedling Raising}

Seedlings of each variety were raised on $2 \mathrm{~m} \times 1 \mathrm{~m}$ (adjacent plots) thoroughly prepared beds, $5 \mathrm{~cm}$ raised from the surface. Seeds were drilled on rows with ten $\mathrm{cm}$ inter-row spacing and it was covered lightly with fine soil and mulched with eucalyptus leaves until emergence. Seedlings were thinned at first true leaf stage to allow 2-3 cm distance within plants (intra-raw spacing). Seedlings were raised under white plastic cover to avoid rain contact with foliage of seedlings. Plastic cover was made at about $75 \mathrm{~cm}$ height from the surface of the seed bed. Watering using watering cans was made just on the soil surface caring to avoid moisture contact with seedling leaves. Weeding was accomplished as deemed necessary. Seedlings generally attained transplantable size in four weeks. Healthy, vigorous and uniform seedlings of pencil size were transplanted in the field. Replanting to replace dead or weak seedlings in field establishment was done a week from transplanting. Seed sowing and seedling transplanting dates in 2018 were on the $23^{\text {rd }}$ of May and $25^{\text {th }}$ of June, 2018, respectively. 


\subsection{Main Field Preparation and Management}

Experimental plot was thoroughly plowed and leveled. Ridges were prepared with $25 \mathrm{~cm}$ height from the furrow. Transplanting was done at a side of a ridge with $40 \mathrm{~cm}$ spacing between plants and 100 cm inter-row spacing.

Inorganic fertilizers in the form of Urea (46:0:0) $(100 \mathrm{~kg} / \mathrm{ha})$ and Nitrate phosphate sulfur (NPS) $(19: 38: 7)(242 \mathrm{~kg} / \mathrm{ha})$ were applied. NPS was applied at transplanting while urea is applied in two splits, the first at seedling establishment (1-2 weeks after transplanting) and the second one and half months after transplanting. Standard field management practices such as weeding and cultivation were performed uniformly during the growing seasons. Tomato plants were supported (staked) with wooden sticks and ropes immediately before flower initiation. These rainy season trials under plastic shelter were designed to water plots by diverting rain collected from the shelter into furrows of each plot. Plastic shelters at 1.5 meter height from the surface of plots were constructed with the support of wooden poles and sticks. These helped to avoid direct contact of rain with tomato stems and leaves.

\section{DATA COLleCtion AND ANALYSIS}

Seedling emergence, vigor and field establishment after transplanting were recorded. Field establishment is noted by counting seedlings that successfully resumed growth after transplanting. Vigor is recorded referring to stiffness of seedlings in a plot, one was recorded for plots with the most weakest seedling while five refers to plots with very strong seedlings.

Data was collected on disease incidence, plot cover, 50 per cent flowering and maturity. Visual judgment is made to record the proportion of the plot surface covered by tomato foliage. Number of days required from transplanting date to the day on which 50\% of the plants in a plot flowered was recorded. Fruit yield was harvested at appropriate maturity time (when fruit color turns to yellow and red) and categorized as marketable and non-marketable fruits.

Marketable fruits are those with average size and above, and are free from visible damages due to diseases, insects and physiological disorder. Marketable fruits were counted and weighed whereas unmarketable fruits were counted and sorted out based on their respective causes, i.e., diseases, insects, physiological disorder or undersized fruits. Data was subjected to analysis of variance using SAS software version 9.2 and least significance difference (LSD) was used to compare treatment means when there was statistically significant difference $(\mathrm{P}<0.05)$.

\section{RESUlt AND DisCUSSIONS}

Early harvest (first harvest) was high from Variety Melkasalsa (23.5 qt/ha) where as the lowest yield was from Variety Gelilema (3.45qt/ha). Varieties Melkshola gave high fresh marketable total yield from the first two consecutive harvests (in the second week) while the lowest yield was still from Variety Gelilema. Variety Melkasalsa followed by Melkashola consistently produced the highest total marketable fresh tomato yield from the third up to the seventh total harvest. The lowest total yield was recorded from Variety Gelilema up to the fifth harvest (112.88qt/ha), whereas, including the last two harvests (sixth and seventh), the lowest cumulative fresh marketable tomato yield was recorded from varieties Cochoro (161.24 qt/ha) and Fetan (158.43qt/ha) (Table 1)

Total marketable fresh tomato yield per plant in $\mathrm{kg}$ was high from variety Melkasalsa $(1.7 \mathrm{~kg} / \mathrm{plant})$ and Melkashola (1.6 kg/plant) and the lowest was from varieties Cochoro $(0.8 \mathrm{~kg} / \mathrm{plant}$ and Fetan $(0.77 \mathrm{~kg} / \mathrm{plant})$. On the other hand, the biggest fruit was from varieties ARP $(5.65 \mathrm{~cm})$ and Eshet $(5.98$ $\mathrm{cm})$, while fruit width is small for varieties Melksalsa $(3.35 \mathrm{~cm})$, Melkashola $(3.38 \mathrm{~cm})$ and Miya $(3.99 \mathrm{~cm})$. Per cent non-marketable fruit number ranged from 20.92 and $21.75 \%$ from varieties Melkashola and Miya, respectively to $35.7 \%$ from variety Eshet and $36.45 \%$ from variety Fetan (Table 2).

Highest yield at a single harvest was obtained from variety Melkasalsa $(6.89 \mathrm{~kg})$, followed by ARP $(5.47 \mathrm{~kg})$ and it was in the fourth harvest. In the last $\left(7^{\text {th }}\right)$ harvest the lowest yield was recorded from varieties ARP (0.14kg) and Fetan (0.22kg) (Figure 1). Likewise Pandey, et al (2006) and Jaiswal et al (1997) reported that BL-410 variety was found the most suitable in terms of good yield, attractive fruit shape and size and comparatively free from insect pest and disease damage. 
Table1. Mean cumulative yield of subsequent weekly harvest in quintal per hectare (qt/ha)

\begin{tabular}{|c|c|c|c|c|c|c|c|}
\hline \multirow[b]{2}{*}{ Variety } & \multicolumn{7}{|c|}{ Mean cumulative yield across weeks } \\
\hline & $\begin{array}{c}1^{\text {st }} \text { harvest } \\
\text { (week 1) }\end{array}$ & $\begin{array}{l}\text { two harvests } \\
\text { (up to week 2) }\end{array}$ & $\begin{array}{c}3 \\
\text { harvests }\end{array}$ & 4 harvests & 5 harvests & $\begin{array}{c}6 \\
\text { harvests }\end{array}$ & $\begin{array}{l}7 \text { harvests } \\
\text { (Total } \\
\text { yield) }\end{array}$ \\
\hline Melkasalsa & $23.5^{\mathrm{a}}$ & $58.53^{\mathrm{a}}$ & $133.39^{\mathrm{a}}$ & $256.45^{\mathrm{a}}$ & $338.46^{\mathrm{a}}$ & $377.70^{\mathrm{a}}$ & $386.68^{\mathrm{a}}$ \\
\hline Melkasl & $18.58^{\mathrm{a}}$ & $59.89^{\mathrm{a}}$ & $125.1^{\mathrm{abc}}$ & $200.03^{\text {abc }}$ & $297.38^{\mathrm{ab}}$ & $359.84^{\mathrm{ab}}$ & $375.68^{\text {ab }}$ \\
\hline Miya & $12.91^{\mathrm{ab}}$ & $36.92^{\mathrm{abc}}$ & $77.79^{\text {abcd }}$ & $157.89^{\mathrm{abcd}}$ & $235.00^{\mathrm{abcd}}$ & $285.06^{\text {abc }}$ & $297.82^{a b c}$ \\
\hline ARP & $14.15^{\mathrm{ab}}$ & $47.67^{\mathrm{ab}}$ & $129.6^{\mathrm{ab}}$ & $227.23^{\mathrm{ab}}$ & $255.98^{\mathrm{abc}}$ & $262.03^{\mathrm{abc}}$ & $264.58^{\mathrm{abc}}$ \\
\hline Metade & $17.76^{\mathrm{ab}}$ & $40.82^{\mathrm{abc}}$ & $93.78^{\text {abcd }}$ & $162.89^{\text {abcd }}$ & $207.54^{\text {bcd }}$ & $235.45^{\mathrm{bc}}$ & $247.35^{\text {abc }}$ \\
\hline & 13.9 & 26 & $56.08^{\text {bcd }}$ & $96.68^{\mathrm{cd}}$ & $163.11^{\mathrm{cd}}$ & $223.59^{\mathrm{bc}}$ & $242.92^{\mathrm{bc}}$ \\
\hline & 19.0 & 52.5 & $93.47^{\mathrm{abcd}}$ & $154.38^{\mathrm{abcd}}$ & $183.96^{\mathrm{bcd}}$ & $211.15^{\mathrm{c}}$ & $227.54^{\mathrm{c}}$ \\
\hline Gelilem & 3.45 & $12.32^{\mathrm{c}}$ & $30.37^{\mathrm{d}}$ & $68.12^{\mathrm{d}}$ & $112.88^{\mathrm{d}}$ & $170.56^{\mathrm{c}}$ & $195.79^{\mathrm{c}}$ \\
\hline Chali & $11.48^{\mathrm{ab}}$ & $35.02^{\mathrm{abc}}$ & $71.31^{\text {abcd }}$ & $129.23^{\mathrm{bcd}}$ & $166.55^{\mathrm{cd}}$ & $188.02^{\mathrm{c}}$ & $194.77^{\mathrm{c}}$ \\
\hline Cochoro & $11.04^{\mathrm{ab}}$ & $22.69^{\mathrm{bc}}$ & $50.64^{\mathrm{cd}}$ & $95.71^{\mathrm{cd}}$ & $122.69^{\mathrm{d}}$ & $151.39^{\mathrm{c}}$ & $161.24^{\mathrm{c}}$ \\
\hline Fetan & $9.24^{\mathrm{ab}}$ & $40.61^{\mathrm{abc}}$ & $87.42^{\text {abcd }}$ & $132.15^{\mathrm{bcd}}$ & $147.90^{\text {cd }}$ & $154.45^{\mathrm{c}}$ & $158.43^{\mathrm{c}}$ \\
\hline LSD (0.05) & 14.31 & 34.89 & 75.65 & 107.24 & 123.80 & 138.92 & 142.58 \\
\hline
\end{tabular}

Table2. Size of tomato fruit, yield per plant and percent non-marketable yield in 2018

\begin{tabular}{|c|c|c|c|}
\hline Variety & $\begin{array}{c}\text { Fruit width } \\
(\mathrm{cm})\end{array}$ & $\begin{array}{c}\text { Yield } \\
\text { plant }^{-1}(\mathrm{~kg})\end{array}$ & $\%$ Non-marketable yield \\
\hline Melkasalsa & $3.35^{\mathrm{f}}$ & $1.7^{\mathrm{a}}$ & $26.51^{\text {abcd }}$ \\
\hline Melkashola & $3.38^{\mathrm{f}}$ & $1.6^{\mathrm{ab}}$ & $20.92^{\mathrm{a}}$ \\
\hline Miya & $3.99^{\mathrm{et}}$ & $1.38^{\text {abcd }}$ & $21.75^{\mathrm{a}}$ \\
\hline ARP & $5.65^{\text {ab }}$ & $1.19^{\text {abcd }}$ & $25.55^{\text {abc }}$ \\
\hline Metadel & $5.40^{\text {abc }}$ & $1.44^{\text {abc }}$ & $32.81^{\text {bbcd }}$ \\
\hline Bishola & $5.34^{\text {abc }}$ & $1.32^{\text {abcd }}$ & $35.71^{\text {cd }}$ \\
\hline Eshet & $5.98^{\mathrm{a}}$ & $1.13^{\text {abcd }}$ & $31.64^{\text {abcd }}$ \\
\hline Gelilema & $4.26^{\text {de }}$ & $0.92^{\text {cd }}$ & $23.75^{\text {ab }}$ \\
\hline Chali & $4.53^{\text {de }}$ & $1.03^{\text {bcd }}$ & $28.00^{\text {abcd }}$ \\
\hline Cochoro & $4.82^{\text {cd }}$ & $0.80^{\mathrm{d}}$ & $36.45^{\text {d }}$ \\
\hline Fetan & $5.29^{\text {bc }}$ & $0.77^{\mathrm{d}}$ & 10.78 \\
\hline LSD & 0.68 & 0.63 & 22.27 \\
\hline CV\% & 8.43 & 30.65 & \\
\hline
\end{tabular}

Although fruit size is small, high marketable tomato yield with best quality has been obtained from varieties Melkasalsa and Melkashola. Farmers' field day was organized and they were impressed by the performance of tomatoes under plastic shelter. They reflected their interest to use the technology on their own farms. When compared with open field production, tomatoes under plastic shelter produced superior fruits with big size free from symptoms of disease and insect attack and other physiological disorders that in turn could help to fetch high price. Mean results from 2016 to 2018 rainy season tomato production under plastic shelter revealed that Varieties Melksalsa and Melkashola yielded high marketable tomato fruit with superior quality, further demonstrating suitability of varieties to rain shelter production practice. Srinivasan (2011) also indicated that protective structures reduce yield losses from insect pests, diseases, and heavy rains, and result in higher productivity and returns per unit area.

Hail and strong winds during the rainy season frequently prevail in many parts of Ethiopia. While tomato production under plastic shelter in 2017 rainy period brought about $484.20 \mathrm{qt} / \mathrm{ha}$ and 460.53qt/ha marketable tomatoes from varieties Melksalsa and Melkashola, respectively (Table 3), prevalence of heavy hail around Fogera center for a single day in September 2017 completely damaged open field tomatoes resulting in no harvest at all. According to Palada et al (2003), sometimes the use of rain shelters can make a difference between harvesting a good crop and harvesting no crop at all. Plastic rain shelters by avoiding leaf contact with moisture would help to control disease development. Moreover, rain shelters protect tomato plants against the impact of heavy rainfall and prevent frequent periods of leaf wetness. Advantages of avoiding or minimizing fungicide spraying in a plastic rain shelter production technology should be stressed to protect man himself and the environment from hazardous effects of fungicides and to sustain the production practices. 
Table3. Marketable and non-marketable yield of varieties under plastic shelter

\begin{tabular}{|c|c|c|c|c|c|c|}
\hline & \multicolumn{2}{|c|}{2016} & \multicolumn{2}{c|}{2017} & \multicolumn{2}{c|}{2018} \\
\hline Variety & $\begin{array}{c}\text { Marketable } \\
\text { yield qt/ha }\end{array}$ & $\begin{array}{c}\text { \% non } \\
\text { marketable } \\
\text { yield }\end{array}$ & $\begin{array}{c}\text { Marketable } \\
\text { yield qt/ha }\end{array}$ & $\begin{array}{c}\% \text { non } \\
\text { marketable } \\
\text { yield }\end{array}$ & $\begin{array}{c}\text { Marketable } \\
\text { yield qt/ha }\end{array}$ & $\begin{array}{c}\% \text { non } \\
\text { marketable } \\
\text { yield }\end{array}$ \\
\hline Melkasalsa & 607.40 & 17.28 & 484.20 & 16.42 & 386.68 & 26.51 \\
\hline Melkashola & 328.48 & 23.46 & 460.53 & 22.26 & 375.68 & 20.92 \\
\hline
\end{tabular}

\section{CONCLUSION AND RECOMMENDATIONS}

Marketable fresh tomatoes produced under plastic shelter were found to be high with best quality free from visible damages due to diseases, insects and physiological disorders enabling growers fetching good market price. Tomato production during the rainy season under plastic shelter enables growers to produce fungicide free fresh tomatoes healthy for human consumption. Environmentally friendly production practices by protecting also from other unexpected natural incidences such as hail and strong wind and rainfall are also among other advantages of this technology. Farmers visited trials under plastic shelters during farmers' field day and they were therefore very much delighted to use this practice of rain-fed tomato production under plastic shelter.

Varieties Melkasalsa and Melkshola produced the highest marketable yield, although fruit width is the smallest. Furthermore, significantly low non-marketable fruit number was recorded for Variety Melkshola. It can be inferred that these two varieties are most suitable to rainy season production under plastic shelter. Pure seed supply and training on the practice of constructing rain shelter and crop management under plastic shelter are issues of major concern for wide spread application of the technology.

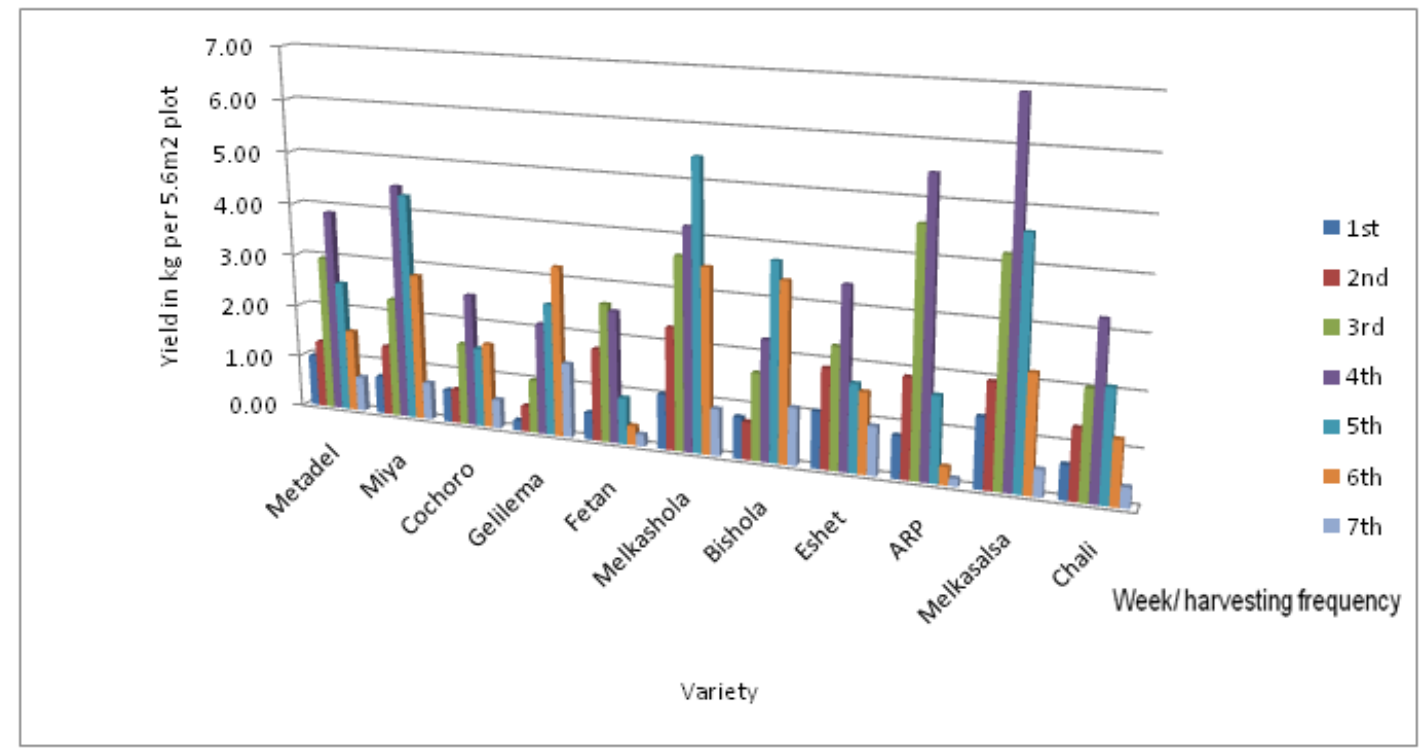

Figure1. Marketable tomato yield of varieties in subsequent weeks (harvests)

\section{ACKNOWLEDGMENT}

Warm season vegetable research team of Mekasa Agricultural Research Center of the Ethiopian Institute of Agricultural Research is acknowledged for providing me with seeds of tomato varieties. I'm also grateful to field assistants and other team members of Fogera Center for their support in field management and data collection.

\section{REFERENCES}

[1] ARC (2013). Production Guideline for summer vegetables, Agricultural Research Council (ARC), Vegetable and ornamental plant Institute Production, Pretoria, South Africa

[2] Dimascio, P.S. Kaiser and H. Sies (1989). Lycopene as the most efficient biological carotenoid single oxygen quencher. Arch. Biochem. Biophys, 274: 532-538.

[3] Getahun, D (2015). Open Field Performance of Tomato Lycopersicon esculentum Mill.) Varieties in the Rainy season at Woreta, South Gondar, Ethiopia. International Journal Scientific Research in Agricultural Sciences 2(5), pp. 117-125 
[4] Getahun, D (2017). The Effect of Planting Periods on Yield and Quality of Fresh Tomatoes Produced in an Open Field under Rain Fed, International Journal of Research Studies in Agricultural Sciences (IJRSAS) Volume 3, Issue 1, 2017, PP 1-8

[5] Ibitoye, DO, Akin-Idowu, PE and Ademoyegun, OT (2009). Agronomic and lycopene evaluation in tomato (Lycopersicon lycopersicum Mill.) as a function of genotype, World Journal of Agricultural Sciences, 5, pp. 892-895

[6] Jaiswal JP, SP Bhattarai and PP Subedi (1997). Varietal and micronutrient trials on spring and rainy season tomato conducted at outreach research sites 1995/96. LARC Working Paper No. 97/22. Lumle Agriculture Research Centre, Kaski, Nepal.

[7] Kirimi JK, Itulya, FM and Mwaja, VN (2011). Effects of nitrogen and spacing on fruit yield of tomato, Afr. J. Hort. Sci. 5:50-60

[8] Palada, M.C., Roan, Y.C., and Black, L.L (2003). Rain shelters for tomato production in the hot-wet season. International Cooperator's Guide, AVRDC Publication Number: 03

[9] Pandey, Y R, A B. Pun and K P. Upadhyay (2006). Participatory Varietal Evaluation of Rainy Season Tomato under Plastic House Condition, Nepal Agric. Res. J. Vol. 7

[10] Srinivasan, R (2011). Vegetable Production under Protective Structures, CGIAR SP-IPM, Technical Innovation Brief, No. 11

[11] Tabasi A, H Nemati, and M Akbari (2013). The Effects of Planting Distances and Different Stages of Maturity on the Quality of Three Varieties of Tomatoes (Lycopersicon esculentum Mill) NotSciBiol, 5(3):371-375

[12] Trinklein, H. David (2010). Growing home garden tomatoes. University of Missouri Extension: http:/extension.missouri.edu/p/G6461

Citation: Dessie Getahun, (2019). "Responses of Tomato Varieties to Rainy Season Production under Low Cost Plastic Shelter" International Journal of Research Studies in Agricultural Sciences (IJRSAS), 5(2), pp.16, http://dx.doi.org/10.20431/2454-6224.0502001

Copyright: (C) 2019 Authors. This is an open-access article distributed under the terms of the Creative Commons Attribution License, which permits unrestricted use, distribution, and reproduction in any medium, provided the original author and source are credited. 